Tomasz Goszczyński ${ }^{l}$

\title{
WPLYW CZYNNIKÓW MIKRO I MAKROOTOCZENIA NA PROCESY INNOWACYJNE ZACHODZĄCE W PRZEDSIEBIORSTWACH
}

\begin{abstract}
Streszczenie: Innowacje to we współczesnym świecie podstawowy warunek nie tylko rozwoju, ale czasem po prostu utrzymania się na rynku. Celem opracowania jest określenie, w jaki sposób czynniki otoczenia wpływają na działalność innowacyjną. Nie ulega wątpliwości, że innowacje mają aspekt wielowymiarowy oraz mają duży wpływ na rozwój gospodarczy, nie tylko poszczególnych regionów, ale i całej gospodarki.
\end{abstract}

Słowa kluczowe: zarządzenie, innowacje, przedsiębiorstwo, mikrootoczenia, makrootoczenie

\section{Wstęp}

Przedsiębiorstwa funkcjonujące na rynku zawsze pozostają we wzajemnej zależności $\mathrm{z}$ otoczeniem. Efektywność ich funkcjonowania $\mathrm{w}$ dużym stopniu warunkowana jest stopniem dostosowania się do różnych elementów tego otoczenia. Współcześnie przedsiębiorstwa funkcjonują w otoczeniu, które jest zmienne i szybko ewoluuje. Aby mogły funkcjonować i rozwijać się muszą aktywnie reagować na zmiany zachodzące $\mathrm{w}$ otoczeniu [1]. Presja ze strony czynników otoczenia nie jest oczywiście taka sama dla wszystkich przedsiębiorstw funkcjonujących w tym samym czasie i w tym samym obszarze. W dużym stopniu zależy ona od pozycji, jaką dane przedsiębiorstwo zajmuje na rynku. I tak, w przypadku dużych przedsiębiorstw, które dysponują znaczącym potencjałem ekonomicznym i finansowym, obserwuje się mniejszą podatność na zmiany zachodzące $\mathrm{w}$ otoczeniu. $\mathrm{Z}$ kolei, przedsiębiorstwa, które zajmują pozycję peryferyjną w swoim sektorze, muszą elastycznie i szybko reagować na wszelkie zmiany zachodzące $\mathrm{w}$ otoczeniu. Należy również pamiętać, że członkostwo Polski w UE spowodowało powstanie nie tylko odmiennego otoczenia miro i marko, ale również nowych struktur rynkowych i zmienionego ustawodawstwa prawnego [2].

Otoczenie przedsiębiorstwa zawiera wszystkie czynniki i procesy, które posiadają wpływ na funkcjonowanie przedsiębiorstwa. Określa ono możliwości rozwoju jednocześnie tworząc szanse, bariery i zagrożenia. W związku z tym musi być uwzględnianie podczas budowania długo- i krótkoterminowej strategii

\footnotetext{
${ }^{1}$ doktor, Politechnika Częstochowska, Wydział Zarządzania, e-mail: tomaszg@ zim.pcz.pl
} 
$\overline{\text { przedsiębiorstwa oraz przy wyznaczaniu jego celów. Jak już wspomniano, otoczenie }}$ ulega ciągłym zmianom, dlatego konieczne jest nieustanne monitorowanie zmian, jakie w nim zachodzą. Z tego punktu widzenia, czynniki warunkujące wdrażanie innowacji można podzielić na dwie grupy tj. czynniki zewnętrzne, które są niezależne od przedsiębiorstwa oraz czynniki wewnętrzne, które poddają się procesowi zarządzania [3].

\section{Wpływ czynników makrootoczenia i mikrootoczenia na procesy innowacyjne}

Według tradycyjnego podziału, środowisko przedsiębiorstwa składa się z makrootoczenia oraz mikrootoczenia [4]. W przypadku makrootoczenia możemy wyróżnić następujące elementy:

1. Ekonomiczne.

2. Polityczno-prawne.

3. Społeczno-kulturowe.

4. Technologiczne.

5. Naturalne.

Ad 1. Otoczenie ekonomiczne jest bardzo ważne w percepcji przedsiębiorstwa ponieważ informuję o aktualnej sytuacji gospodarki obszaru do której przynależy przedsiębiorstwo. W związku z tym dotyczy rentowności i potencjalnych zysków/strat wynikających z funkcjonowania w określonym środowisku.

Ad 2. W otoczeniu polityczno-prawnym zawarte są ustalenia, które zostały wprowadzone przez ustawodawstwo. Stanowią one zbiór regulacji prowadzenia działalności gospodarczej. Odpowiadają również za relacje między państwem i gospodarką.

Ad 3. Otoczenie społeczno-kulturowe zawiera zbiór nawyków, cech demograficznych społeczeństwa, norm, nawyków i zwyczajów, które wpływają na przedsiębiorstwo.

Ad 4. Otoczenie technologiczne posiada bardzo dużą dynamikę rozwoju co jest szansą dla przedsiębiorstw i również jest zagrożeniem dla pozostałych. Dotyczy ono nie tylko procesu wytwarzania produktu przedsiębiorstwa Technologia ma wpływ na sposoby transportu, przechowywania półproduktów i produktów, techniki handlu, wzornictwo i projektowanie. W ostatnich latach $\mathrm{XX}$ wieku zmiany technologiczne dotyczyły głównie rozwoju informatyki, sposobu komunikacji.

Ad 5. Naturalne środowisko posiada czynniki, którymi m.in. są klimat, topografia terenu. Należy również zaliczyć do tego otoczenia dostępność zasobów naturalnych. Siła ich wpływu dostępności zależy od charakteru prowadzonej działalności. 
Cechą charakterystyczną makrootoczenia jest to, że bardzo mocno określa możliwości rozwoju przedsiębiorstw, zaś przedsiębiorstwa nie są $\mathrm{w}$ stanie oddziaływać na zmiany tych warunków. Wyjątkiem są tylko bardzo duże przedsiębiorstwa (korporacje) o ogromnym potencjale finansowym i zapleczu politycznym, które mogą podejmować próby wpływania na niektóre z czynników makrootoczenia.

W odróżnieniu od makrootoczenia, mikrootoczenie może być zmieniane w kierunku pożądanym przez przedsiębiorstwa [5]. Mikrootoczenie określa warunki funkcjonowania i rozwoju przedsiębiorstw na określonym rynku i $\mathrm{w}$ określonej branży. Jego cechą charakterystyczną jest występowanie tzw. sprzężenia zwrotnego, które polega na tym, że podmioty znajdujące się $\mathrm{w}$ otoczeniu przedsiębiorstwa oddziałują na nie pozytywnie lub negatywnie, ale przedsiębiorstwo może aktywnie reagować na te zmiany. Mikrootoczenie obejmuje podmioty związane z przedsiębiorstwem i jego działalnością od klientów poprzez dostawców, na konkurencji kończąc. Dokładne przeanalizowanie sektora działalności przedsiębiorstwa pozwala na ocenę jego atrakcyjności oraz szans i zagrożeń, które stwarza. Krótko mówiąc są to czynniki zewnętrzne, konkretne organizacje lub grupy, które mogą mieć wpływ na działanie przedsiębiorstwa. Wpływają bezpośrednio na jego działanie [6].

Aby w pełni zanalizować otoczenie konkurencyjne przedsiębiorstwa, należy je poprzedzić analizą makrootoczenia firmy, gdyż ogólne i podstawowe dane dla całego przemysłu są punktem odniesienia do oceny obecnego stanu i perspektyw rozwojowych sektora. Warto pamiętać, że liczba podmiotów wchodzących w skład mikrootoczenia nie jest stała. Przedsiębiorstwo powinno więc monitorować zmiany zachodzące w jego bliższym jak i dalszym otoczeniu. Granica między czynnikami znajdującymi się $\mathrm{w}$ otoczeniu bliższym $\mathrm{i}$ w otoczeniu dalszym jest często nieostra. Wiele zmian $w$ najbliższym otoczeniu przedsiębiorstwa jest bowiem konsekwencją zmian zachodzących w makrootoczeniu. Jednak można wyróżnić pewne grupy czynników, które charakterystyczne są dla otoczenia bliższego. Do czynników mikrootoczenia zaliczamy [7]:

1. Dostawców - przedsiębiorstwa bądź osoby fizyczne dostarczające zasobów potrzebnych w firmie do realizacji prowadzonej działalności.

2. Nabywców - ostateczni odbiorcy oferty marketingowej przedsiębiorstwa.

3. Pośredników - firmy wspierające działalność przedsiębiorstwa, głównie w promocji, dystrybucji i sprzedaży produktów finalnym odbiorcom.

4. Konkurentów - wszystkie firmy wytwarzające te same produkty albo substytuty lub działające w tym samym segmencie rynku.

5. Lokalną społeczność (związki zawodowe, siła robocza). 
Ad 1. Dostawcy to organizacje dostarczające zasoby (środki produkcji, nośniki energii) innym podmiotom rynkowym. Siła przetargowa dostawców zależy podobnie jak wśród odbiorców od: stopnia koncentracji dostawców w stosunku do odbiorców w sektorze, uzależnienia jakość wyrobu końcowego od jakości zasobów nabywanych od dostawcy, pozycji monopolistycznej odbiorcy i dostawcy, udziału kosztów tworzonych przez dostawców w całkowitym koszcie odbiorcy, wysokości kosztów zmiany dostawcy, groźby podjęcia produkcji wyrobu finalnego przez dostawcę. Właściwa analiza dostawców pozwala nawiązać współpracę z tymi, którzy mogą stać się w przyszłości partnerami przedsiębiorstwa i stymulować jego rozwój, a także ograniczyć wysokość kosztów związanych z dostawą. Organizacje powinny unikać uzależnienia się od jednego dostawcy. Może to mieć negatywny wpływ na działanie firmy w momencie powstania wewnętrznych problemów dostawcy lub wyeliminowania go z rynku.

Ad 2. Odbiorcy indywidualni jak i instytucjonalni to najliczniejsza $\mathrm{z}$ grup wchodzących w skład mikrootoczenia przedsiębiorstwa obejmująca obecnych i potencjalnych klientów. Odbiorcy odgrywają kluczową rolę w analizie otoczenia przedsiębiorstwa ze względu na swoją siłę negocjacyjna, na którą wpływa m.in. stopień ich koncentracji, udział produktu w koszyku i budżecie zakupów, standaryzacja produktu, znaczenie naszego wyrobu dla jakości wyrobu końcowego, a także stopień poinformowania o sytuacji firmy. Dane o klientach przedsiębiorstwa uzyskują zazwyczaj z przeprowadzonych badań marketingowych, z których otrzymują istotne informacje dotyczące segmentów nabywców, ich potrzeb, motywów oraz preferencji zakupowych. Mogą oni również wpływać na poziom i kierunki inwestycji w rozwój pracowników. Im większe wymagania względem jakości produktów i/lub usług tym większa potrzeba dokształcania pracowników poprzez dodatkowe szkolenia, a także wprowadzenie nowych metod produkcyjnych.

Ad 3. Pośrednicy to podmioty rynku, które uczestniczą w rozprowadzaniu (dystrybucji) produktów przedsiębiorstwa do odbiorców. Zazwyczaj przejmują oni prawo własności do produktu finalnego na drodze od producenta dobra aż po jego konsumenta. Analizując pośredników należy zastanowić się nad tym, czy przedsiębiorstwo potrzebuje pomocy $\mathrm{w}$ rozprowadzaniu swoich dóbr, a także czy korzystanie $\mathrm{z}$ ich usług obniży przeciętny koszt dystrybucji. Jeśli fachowość i zdolność pośredników w docieraniu do finalnych konsumentów oraz stwarzane przez nich odpowiednie warunki zakupowe produktów przewyższają zdolności samego przedsiębiorstwa, które nie jest w stanie zapewnić sobie wystarczająco dużego popytu na produkowane dobra, to występowanie pośrednika w kanale dystrybucji jest uzasadnione.

Ad 4. Konkurentami są zazwyczaj firmy mające podobny profil działalności i zatrudniają pracowników o podobnych kompetencjach. Konkurencja to proces, w którym podmioty rynkowe konkurują ze sobą w zawieraniu transakcji rynkowych, 
poprzez przedstawianie korzystniejszej od innych podmiotów oferty rynkowej dla zrealizowania swoich interesów. Konkurowanie może się odbywać w oparciu o cenę, jakość, formę płatności i wiele innych.

Ad 5. Lokalne społeczności, w których skład wchodzą: ludzie mieszkający w najbliższej okolicy, lokalne media, grupy wyznaniowe, związki zawodowe czy organizacje obywatelskie. Grupy te stanowią ważny rynek pracy dla przedsiębiorstwa. Decydują one o powodzeniu firmy na danym rynku. Kształtują opinię na temat przedsiębiorstwa i jego wyrobów, a także dostarczają zasobów siły roboczej.

Praktyka gospodarcza pokazuje, że przedsiębiorcy, którzy dopiero zaczynają przygodę z biznesem korzystają ze sprawdzonych metod analiz, takich jak: analiza SWOT, analiza konkurencji, analiza zachowania konsumentów.

\section{Analiza wpływu czynników makrootoczenia i mikrootoczenia na procesy innowacyjne zachodzące $w$ przedsiębiorstwach}

Prowadzone badania empiryczne w sektorze małych i średnich przedsiębiorstw województwa śląskiego, potwierdziły istotną rolę czynników markootoczenia i mikrootoczenia w procesie realizacji innowacji. Ich analiza pozwoliła na wyodrębnienie dwóch grup czynników tj.: przyspieszających wzrost prowadzonej działalności innowacyjnej, oraz hamujących ten wzrost.

Opierając się na dostępnej literaturze przedmiotu dokonano identyfikacji kilkunastu czynników kształtujących otoczenie badanych przedsiębiorstw.

W przypadku przedsiębiorstw wchodzących w skład sektora prywatnego dominowała ocena, iż czynniki makrootoczenia przeważnie negatywnie wpływają na działalność innowacyjną. Zdecydowanie największy negatywny wpływ zaobserwowano $\mathrm{w}$ przypadku takich czynników jak: wydatki związane z przygotowaniem dokumentacji przy ubieganiu się o środki na działalność innowacyjną, skomplikowane i niejasne przepisy prawa, podatki, koszty uzyskania kredytu. Część z czynników okazała się neutralna, tj. procedury certyfikacyjne i patentowe, czy ochrona konkurencji i konsumentów. Natomiast największy pozytywny wpływ na działalność innowacyjną uzyskały ulgi podatkowe oraz polityka proinnowacyjna państwa (rys. 1). 


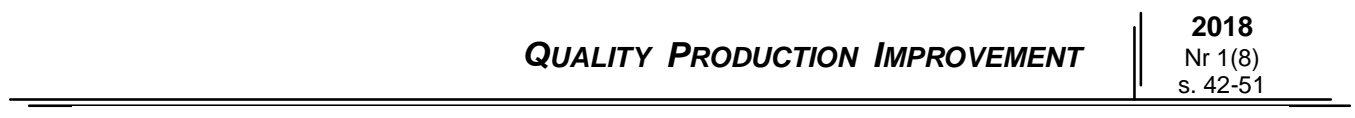

\section{wpływ pozytywny abrakwpływu wpływnegatywny}

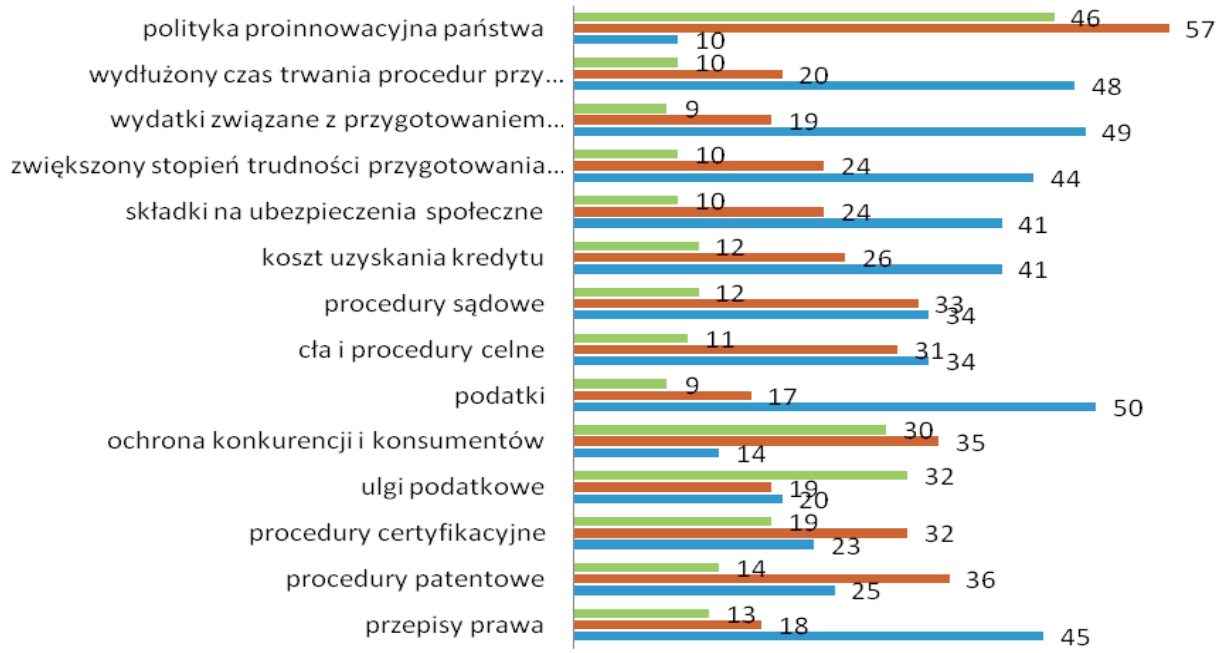

Rys. 1. Wpływ czynników makrootoczenia na procesy innowacyjne w przedsiębiorstwach z sektora prywatnego

Źródto: opracowanie własne

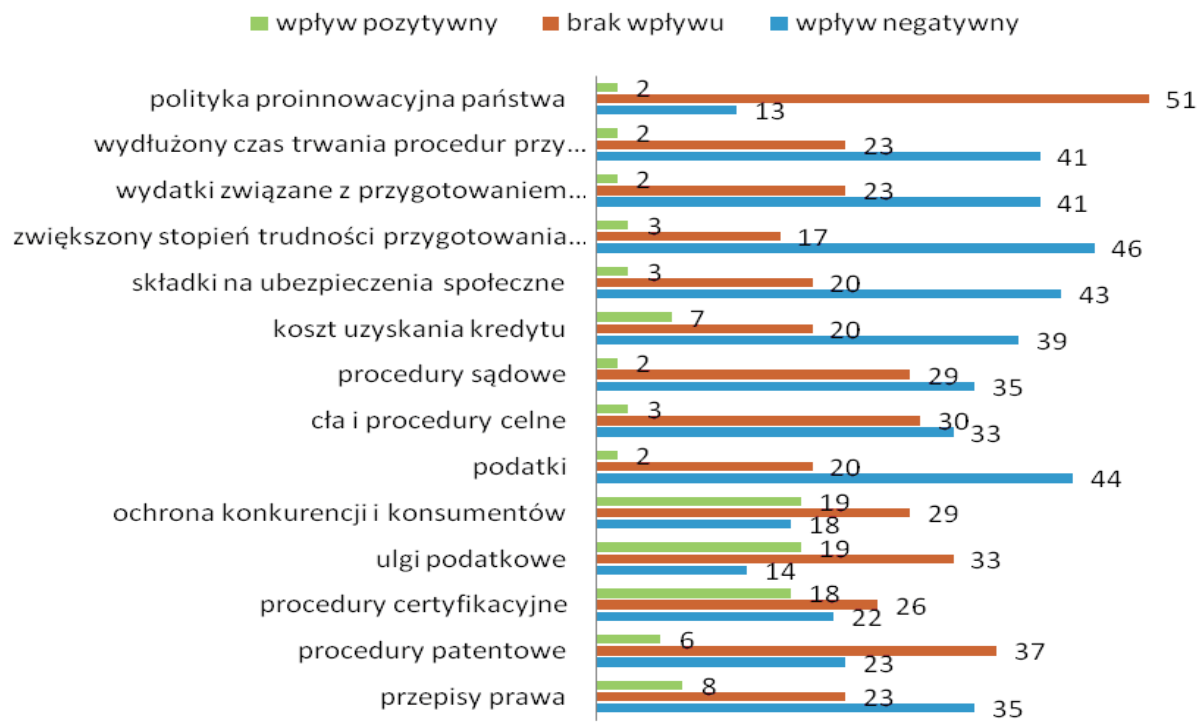

Rys. 2. Wpływ czynników makrootoczenia na procesy innowacyjne w przedsiębiorstwach z sektora publicznego

Źródto: opracowanie własne 
W przypadku przedsiębiorstw wchodzących w skład sektora publicznego największy negatywny wpływ mają: trudności w przygotowaniu dokumentacji przy ubieganiu się o środki na działalność innowacyjną, podatki, składki na ubezpieczenia społeczne oraz koszty uzyskania kredytu. Do czynników o neutralnym charakterze można zaliczyć: politykę proinnowacyjną państwa, procedury patentowe, czy ulgi podatkowe. Natomiast największy pozytywny wpływ na działalność innowacyjną uzyskały ulgi podatkowe oraz ochrona konkurencji i konsumentów (rys. 2).

Przechodząc do omówienia wpływu czynników mikrootoczenia można zauważyć, że w przypadku przedsiębiorstw z sektora publicznego, prawie wszystkie czynniki zostały ocenione negatywnie. Największy negatywny wpływ mają cztery czynniki tj. zbyt małe zyski przedsiębiorstwa, wysokie koszty pracy, ciągły wzrost kosztów produkcji oraz problemy z zapewnieniem płynności finansowej (rys. 3).

$$
\text { wpływ pozytywny abrakwpływu awpływ negatywny }
$$

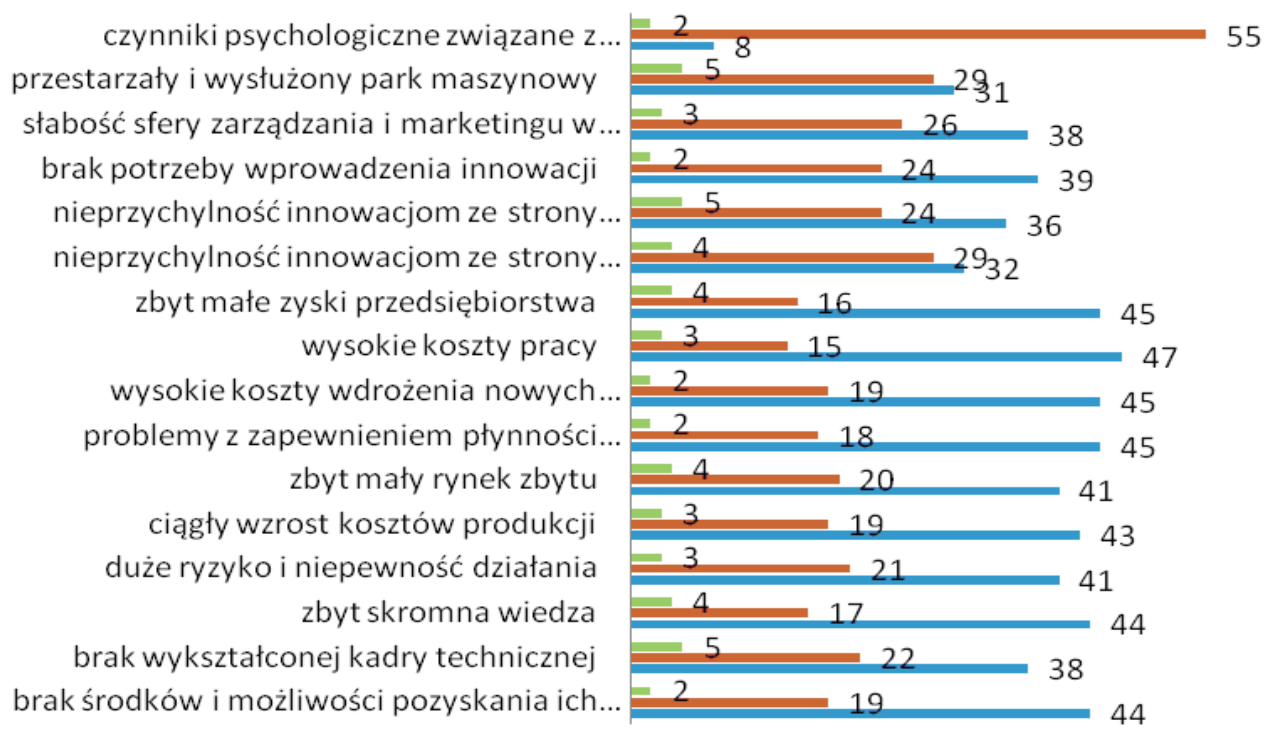

Rys. 3. Wplyw czynników mikrootoczenia na procesy innowacyjne w przedsiębiorstwach z sektora publicznego

Źródło: opracowanie własne

Ocena czynników mikrootoczenia nie uległa zbyt większym zmianom $\mathrm{W}$ odniesieniu do przedsiębiorstw $\mathrm{z}$ sektora prywatnego. Podobnie jak przedsiębiorstwa $\mathrm{z}$ sektora publicznego, także podmioty prywatne negatywnie oceniły 
$\overline{\text { większość czynników mikrootoczenia. Zdecydowanie największy negatywny wpływ }}$ odgrywają: wysokie koszty pracy, ciągły wzrost kosztów produkcji czy zbyt mały rynek zbytu. Z kolei, do czynników o neutralnym wpływie zaliczyć należy czynniki psychologiczne związane z podejściem kierownictwa do innowacji (rys. 4).

wpływ pozytywny brakwpływu wpływ negatywny

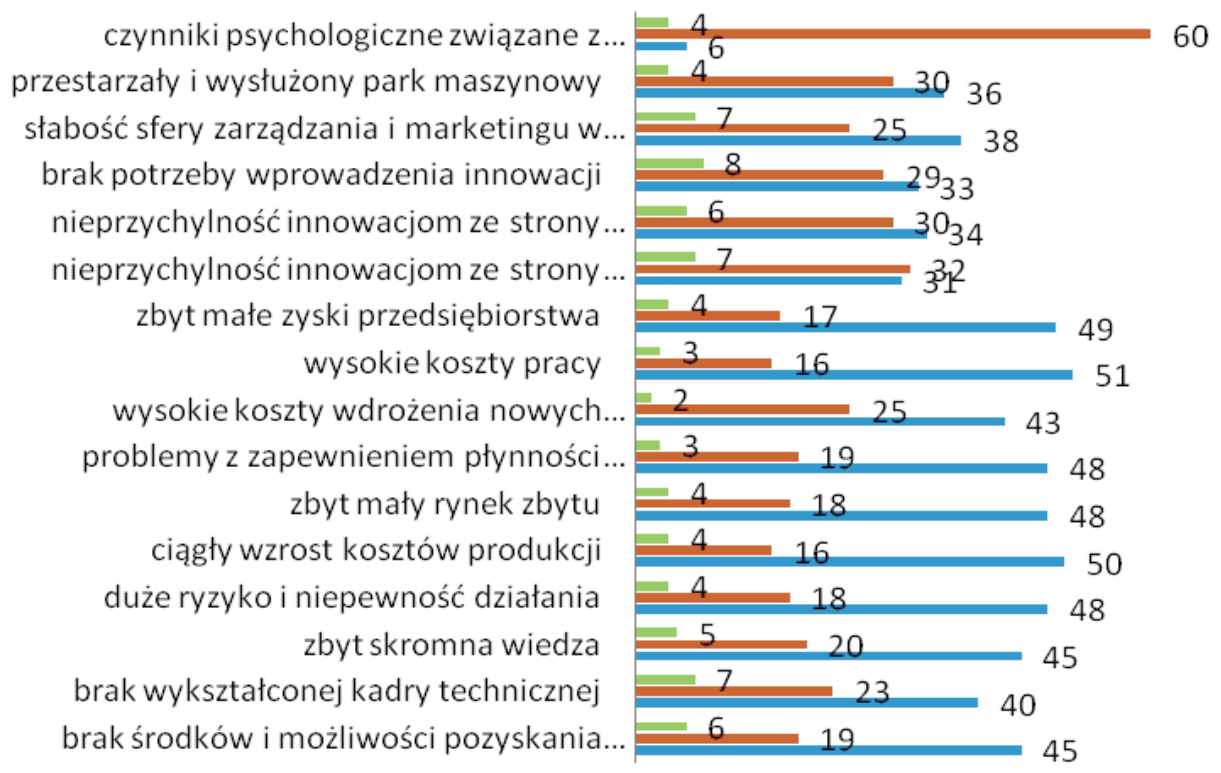

\section{Rys. 4. Wplyw czynników mikrootoczenia na procesy innowacyjne w przedsiębiorstwach z sektora prywatnego}

Źródło: opracowanie własne

Dokonując analizy przedstawionych wyników badań, nasuwa się wniosek, że im większy obszar działania, tym niesprzyjający wpływ czynników mikrootoczenia zmniejsza się, a nawet zastąpiony zostaje wpływem pozytywnym.

\section{Zakończenie}

Procesy innowacyjne są zagadnieniem bardzo obszernym, które może być omawiane z różnych punktów widzenia i w różnych płaszczyznach [8]. Przedmiotem niniejszego artykułu było ukazanie tylko jednego z kilku aspektów tego procesu, oraz zidentyfikowanie najważniejszych elementów wpływających na ten proces. Prowadzenie działalności innowacyjnej to często już nie tylko sposób na uzyskanie przewagi nad konkurencją i zdobycie pozycji lidera, lecz także warunek sine qua non 
utrzymania się na rynku dla wielu polskich przedsiębiorstw. Zwłaszcza dla małych i średnich firm wprowadzanie nowych produktów, usług czy też technologii okazuje się niezbędne, by np. dotrzymać kroku dużym przedsiębiorstwom. Konieczne jest także bieżące monitorowanie zmieniających się potrzeb klientów, których wymagania stają się coraz wyższe. Jest to zwłaszcza konieczne w przypadku rozpoczynania działalności gospodarczej. Niezbędne jest wtedy przeprowadzenie analizy otoczenia. Uzyskane wnioski umożliwią rozpoznanie swoich szans, zagrożeń i ograniczeń, które istnieją w otoczeniu. Niewątpliwie uzyskana w ten sposób wiedza pomoże $\mathrm{w}$ przygotowaniu odpowiedniej strategii. Niezależnie od powyższego należy stwierdzić, że każde przedsiębiorstwo powinno reagować na zamiany zachodzące w otoczeniu. Nie na wszystkie zjawiska w obrębie tego otoczenia przedsiębiorstwo ma bezpośredni wpływ, o czym była już mowa, jednak one same mają duży wpływ na działalność przedsiębiorstw.

\section{Bibliografia}

[1] Goszczyński T., Potrzeby wdrażania innowacji w przedsiębiorstwach przemystowych" w: Wąsowicz M., Determinanty rozwoju i integracji krajów europejskich, Kolegium Nauk Społecznych i Administracji PW, Warszawa 2007, s. 242.

[2] Penc J., Innowacje i zmiany w firmie, Wyd. Agencja Wydawnicza Placet, Warszawa 1999, str. 20.

[3] Gościński W.J., Cykl życia organizacji, Wyd. PWN, Warszawa 1989, str. 61.

[4] Pomykalski A., Zarzadzanie innowacjami, Wyd. PWN, Warszawa-Łódź 2001, str. 50.

[5] Gierszewska G., Romanowska M., Analiza strategiczna przedsiębiorstwa, Wyd. PWE, Warszawa 2014, str. 23.

[6] Red. Mazur J., Decyzje marketingowe w przedsiębiorstwie, Wyd. Difin, Warszawa 2002, str. 59.

[7] Gołębiewski T., Zarządzenie strategiczne. Planowanie I kontrola, Wyd. Difin, Warszawa 2001, str. 117.

[8] Kotler Ph, Amstrong G., Sauders J., Wong V., Marketing, Podręcznik europejski, Wyd. PWE, Warszawa 2002, str. 182. 


\title{
THE IMPACT OF MICROENVIRONMENTAL AND \\ MACROENVIRONMENTAL FACTORS ON THE INNOVATION PROCESSES TAKING PLACE IN THE ENTERPRISES
}

\begin{abstract}
Innovation is in the modern world the basic condition not only of development, but sometimes simply of staying on the market. The aim of the study is to determine how the environmental factors affect innovative activity. There is no doubt that innovations have a multidimensional aspect and have a big impact on economic development, not only of individual regions, but also of the entire economy.
\end{abstract}

Key words: management, innovations, enterprise, microenvironment, macro environment.

Data przestania publikacji do Redakcji: 10.05.2018

Data akceptacji publikacji przez Redakcję: 15.06.2018 